\title{
Influences of dietary Eucommia ulmoides extract on growth, flesh quality, antioxidant capacity and collagen-related genes expression in grass carp (Ctenopharyngodon idellus)
}

\author{
Hang Yang \\ Shanghai Ocean University \\ Sumei Tan \\ Shanghai Ocean University \\ Xiaoqin Li \\ Shanghai Ocean University \\ Zhen Xu \\ Shanghai Ocean University \\ Zhuo Cheng \\ Shanghai Ocean University \\ Xiang-jun Leng ( $\boldsymbol{\nabla}$ xjleng@shou.edu.cn ) \\ Shanghai Ocean University https://orcid.org/0000-0002-0164-5463
}

\section{Research}

Keywords:

Posted Date: April 13th, 2020

DOI: https://doi.org/10.21203/rs.3.rs-21313/v1

License: (c) (i) This work is licensed under a Creative Commons Attribution 4.0 International License.

Read Full License

Version of Record: A version of this preprint was published at Animal Feed Science and Technology on July 1st, 2021. See the published version at https://doi.org/10.1016/j.anifeedsci.2021.114965. 


\section{Abstract}

Background: The study investigated the effects of dietary Eucommia ulmoides extracts on growth, flesh quality and collagen-related genes expression of grass carp (Ctenopharyngodon idella). Eucommia ulmoides bark extract (EBE) and Eucommia ulmoides leaf extract (ELE) were individually supplemented into basal diet (control) at an inclusion of $4 \mathrm{~g} / \mathrm{kg}$, and then the three diets were fed to grass carp (59.7 \pm $0.3 \mathrm{~g})$ for 60 days.

Results: The results indicated that dietary ELE significantly increased weight gain $(+4.22 \%)$, and decreased feed conversion ratio $(-0.07)(P<0.05)$, while EBE did not significantly affect the growth performance of grass carp. Compared to the control, dietary ELE increased apparent digestibility coefficient of dry matter, crude protein and intestinal digestive enzyme activity $(P<0.05)$, and the contents of calcium, total collagen, heat-insoluble collagen and free amino acids level (including delicious amino acids) in flesh were also increased $(P<0.05)$. In both extracts groups, the flesh centrifugal loss, steaming loss, drip loss ${ }^{24 h}$, protein carbonyl and malondialdehyde were significantly lower, and superoxide dismutase and glutathione peroxidase activities were higher than the control $(P<0.05)$. No significant differences in the amount of saturated, monounsaturated and polyunsaturated fatty acids in flesh were found among the three groups, but DPA, DHA, n-3 polyunsaturated fatty acids and $n-3 / n-6$ ratio in flesh were increased by dietary EBE and ELE $(P<0.05)$. In collagen-related genes expression, the ELE

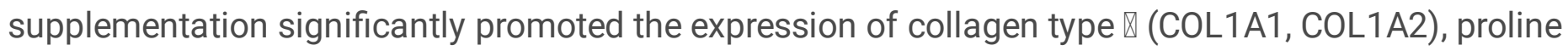
hydroxylase, lysine oxidasein in muscle, while the expression of matrix metalloproteinase-2 and matrix metalloproteinase-9 was decreased $(P<0.05)$.

Conclusion: In conclusion, dietary ELE improved the growth, muscle antioxidant capacity and flesh quality of grass carp.

\section{Background}

The development of intensive aquaculture produced a large amount of aquatic foods for human, but on the other hand, it also brought water pollution and the increased harmful microorganisms, which damaged the health and adversely affected the growth and flesh quality of fish [1]. Antibiotics have been banned or strictly restricted in various countries for its accumulation in flesh and drug resistance, thus herbal plants are becoming effective alternatives for antibiotics [2]. As a traditional herb widely used in East Asia, Eucommia ulmoides (EU) has many functions in human including enhancing bones strength, antioxidant capacity, immunity and reducing body fattiness[3]. In recent years, EU has been reported as feed additive in rabbit [4], pig [5, 6], chicken [7, 8] and fish [9-11]. Studies have shown that EU promoted the flesh quality by increasing muscle collagen of aquatic animals, such as eel Anguilla japonica[12], crucian carp Carassius auratus gibelio [13], grass carp Ctenopharyngodon idellus [9, 14] and white shrimp Penaeus vannamei [15], but the mechanism is unclear. 
When herbal plants were directly added in diets, the inclusion levels were usually high with relatively higher anti-nutritional factors. Thus, extracting active compounds from the raw herbs is an important strategy for the application of herbal plants in the future. The traditional medicinal part of EU is the bark, but in recent years, the leaves have attracted more attentions in feed industry due to the scarcity of bark resources. The inclusion of Eucommia leaf extracts (ELE) in diets has been found in lamb [16], rabbit [17], chicken [18] and pig [19-20].

Grass carp (Ctenopharyngodon idellus) is an important cultured freshwater fish in China with a production of 5.50 million tons in 2018 [21]. In past years, we have conducted a series trials to investigate the effects of dietary EU (bark) [9] and its active compounds including chlorogenic acid [22], quercetin [23], geniposide [24] and geniposidic acid [25] on the growth and flesh quality of grass carp, but the mechanism of flesh quality-improving and collagen-promoting effects is still unclear. Moreover, how about the effects of EU leaf extract when compared to EU bark extract? Therefore, Eucommia bark extracts (EBE) and ELE were supplemented in feed to investigate their effects on growth, flesh quality and collagen-related genes expression of grass carp by biochemical, molecular analysis and flesh quality evaluation.

\section{Materials And Methods}

\section{Experimental design and feeding management}

The basal diet was designed to contain $300 \mathrm{~g} / \mathrm{kg}$ crude protein with the inclusion of fish meal, soybean meal, rapeseed meal and cottonseed meal as the protein sources. Then, EBE and ELE were supplemented in basal diet (control) with an inclusion of $4 \mathrm{~g} / \mathrm{kg}$ and $4 \mathrm{~g} / \mathrm{kg}$, respectively. EBE and ELE were supplied by Xi'an Huilin Bio-Tech Co., Ltd (Xi'an, China), and $1 \mathrm{~kg}$ of EBE and ELE was produced from $5 \mathrm{~kg}$ of bark and $10 \mathrm{~kg}$ of leaves, respectively. The composition of both extracts is shown in Table 1. The supplemental level of EBE and ELE was calculated by referring to the studies of Sun et al. [9] and Leng et al. [26], respectively. In addition, $\mathrm{Y}_{2} \mathrm{O}_{3}$ was used as marker to measure the digestibility. All ingredients were ground, sifted, mixed and pelleted as described by Sun et al. [22], and then all diets were air-dried and stored at $4{ }^{\circ} \mathrm{C}$ until use. The ingredients and proximate composition of experimental diets are shown in Table 2.

Table 1

The composition of Eucommia extracts

\begin{tabular}{|lll|}
\multicolumn{1}{l}{$(\mathrm{g} / \mathrm{kg})$} & \\
\hline Parameters & EBE & ELE \\
\hline Total phenolic acids & 50.1 & 85.8 \\
\hline Total flavonoids & 36.3 & 95.4 \\
\hline Total polysaccharides & 81.0 & 112.3 \\
\hline
\end{tabular}


Table 2

Ingredients and proximate composition of experimental diets $(\mathrm{g} / \mathrm{kg})$

\begin{tabular}{|c|c|c|c|}
\hline Ingredints & Control & EBE & ELE \\
\hline Fish meal & 20.0 & 20.0 & 20.0 \\
\hline Soybean meal & 180.0 & 180.0 & 180.0 \\
\hline Cottonseed meal & 150.0 & 150.0 & 150.0 \\
\hline Rapeseed meal & 190.0 & 190.0 & 190.0 \\
\hline Wheat bran & 102.5 & 98.5 & 98.5 \\
\hline Defatted rice bran & 100.0 & 100.0 & 100.0 \\
\hline Wheat middling & 220.0 & 220.0 & 220.0 \\
\hline Soybean oil & 10.0 & 10.0 & 10.0 \\
\hline $\mathrm{Ca}\left(\mathrm{H}_{2} \mathrm{PO}_{4}\right)_{2}$ & 15.0 & 15.0 & 15.0 \\
\hline Vitamin premix & 2.0 & 2.0 & 2.0 \\
\hline Choline chloride (500 g/kg) & 5.0 & 5.0 & 5.0 \\
\hline Mineral premix & 5.0 & 5.0 & 5.0 \\
\hline $\mathrm{Y}_{2} \mathrm{O}_{3}$ & 0.5 & 0.5 & 0.5 \\
\hline EBE & - & 4.0 & - \\
\hline ELE & - & - & 4.0 \\
\hline Total & 1000.0 & 1000.0 & 1000.0 \\
\hline \multicolumn{4}{|l|}{ Proximate composition } \\
\hline Moisture & 94.2 & 93.5 & 94.5 \\
\hline Crude protein & 300.4 & 302.2 & 299.5 \\
\hline \multicolumn{4}{|c|}{ EBE, Eucommia bark extract; ELE, Eucommia leaf extract } \\
\hline \multicolumn{4}{|c|}{$\begin{array}{l}\text { The ingredients were purchased from the Yuehai Feed Company (Zhejiang, China), and the protein } \\
\text { contents of ingredients are as follow: fish meal }(630.0 \mathrm{~g} / \mathrm{kg}) \text {, soybean meal }(442.0 \mathrm{~g} / \mathrm{kg}) \text {, cottonseed } \\
\text { meal }(500.0 \mathrm{~g} / \mathrm{kg}) \text {, rapeseed meal }(377.0 \mathrm{~g} / \mathrm{kg}) \text {, wheat middling }(169.0 \mathrm{~g} / \mathrm{kg}) \text {, defatted rice bran } \\
(143.0 \mathrm{~g} / \mathrm{kg}) .\end{array}$} \\
\hline \multicolumn{4}{|c|}{$\begin{array}{l}\text { Vitatim premix (mg or IU/kg diet): VA, } 10000 \mathrm{IU} ; \mathrm{VD}_{3}, 3000 \mathrm{IU} ; \mathrm{VE} 150 \mathrm{IU} ; \mathrm{VK}_{3}, 12.17 \mathrm{mg} ; \mathrm{VB}_{1,} 20 \mathrm{mg} ; \\
\mathrm{VB}_{2,} 20 \mathrm{mg} ; \mathrm{VB}_{3,}, 100 \mathrm{mg} ; \mathrm{VB}_{6}, 22 \mathrm{mg} \mathrm{VB}_{12}, 0.15 \mathrm{mg} ; \mathrm{VC}, 1000 \mathrm{mg} \text {; biotin, } 0.6 \mathrm{mg} \text {; folic acid, } 8 \mathrm{mg} \text {; } \\
\text { inositol, } 500 \mathrm{mg} \text {. }\end{array}$} \\
\hline \multicolumn{4}{|c|}{$\begin{array}{l}\text { Mineral premix (mg/kg diet): I, } 1.5 \text { mg; Co, } 0.6 \text { mg; Cu, } 3 \text { mg; Fe, } 63 \text { mg; Zn, } 89 \text { mg; Mn, } 11.45 \text { mg; Se, } \\
0.24 \text { mg; Mg, } 180 \text { mg. }\end{array}$} \\
\hline
\end{tabular}




\begin{tabular}{|c|c|c|c|}
\hline Ingredints & Control & EBE & ELE \\
\hline Crude lipid & 42.9 & 42.7 & 43.2 \\
\hline Crude ash & 70.4 & 69.8 & 69.8 \\
\hline \multicolumn{4}{|c|}{ EBE, Eucommia bark extract; ELE, Eucommia leaf extract } \\
\hline \multicolumn{4}{|c|}{$\begin{array}{l}\text { The ingredients were purchased from the Yuehai Feed Company (Zhejiang, China), and the protein } \\
\text { contents of ingredients are as follow: fish meal }(630.0 \mathrm{~g} / \mathrm{kg}) \text {, soybean meal }(442.0 \mathrm{~g} / \mathrm{kg}) \text {, cottonseed } \\
\text { meal }(500.0 \mathrm{~g} / \mathrm{kg}) \text {, rapeseed meal }(377.0 \mathrm{~g} / \mathrm{kg}) \text {, wheat middling }(169.0 \mathrm{~g} / \mathrm{kg}) \text {, defatted rice bran } \\
(143.0 \mathrm{~g} / \mathrm{kg}) \text {. }\end{array}$} \\
\hline \multicolumn{4}{|c|}{$\begin{array}{l}\text { Vitatim premix (mg or IU/kg diet): VA, } 10000 \mathrm{IU} ; \mathrm{VD}_{3}, 3000 \mathrm{IU} ; \mathrm{VE} 150 \mathrm{IU} ; \mathrm{VK}_{3}, 12.17 \mathrm{mg} ; \mathrm{VB}_{1}, 20 \mathrm{mg} ; \\
\mathrm{VB}_{2}, 20 \mathrm{mg} ; \mathrm{VB}_{3,}, 100 \mathrm{mg} \mathrm{VB}_{6}, 22 \mathrm{mg} \mathrm{VB}_{12}, 0.15 \mathrm{mg} ; \mathrm{VC}, 1000 \mathrm{mg} \text {; biotin, } 0.6 \mathrm{mg} \text {; folic acid, } 8 \text { mg; } \\
\text { inositol, } 500 \mathrm{mg} \text {. }\end{array}$} \\
\hline \multicolumn{4}{|c|}{$\begin{array}{l}\text { Mineral premix (mg/kg diet): I, } 1.5 \text { mg; Co, } 0.6 \text { mg; Cu, } 3 \text { mg; Fe, } 63 \text { mg; Zn, } 89 \text { mg; Mn, } 11.45 \text { mg; Se, } \\
0.24 \mathrm{mg} ; \mathrm{Mg}, 180 \text { mg. }\end{array}$} \\
\hline
\end{tabular}

Grass carp were obtained from Jinshan Aquaculture Farm (Shanghai, China). One hundred and sixty-two grass carp with an average initial weight of $59.7 \pm 0.2 \mathrm{~g}$ were randomly distributed into 9 cages $(1.5 \times 1.0$ $\times 1.2 \mathrm{~m}$ ) with 18 fish per cage. During the experimental period, the fish were fed with a daily feeding rate of $3-5 \%$ of body weight with three meals $(7: 00,12: 00,17: 00)$ per day for 60 days. The feed intake of all cages was appropriately adjusted according to water temperature, and maintained with a similar amount to ensure no feed residue left. The waste in the pools was cleared by siphoning every 5 days, and $1 / 3$ cultured water was renewed with pond water. The dissolved oxygen was not less than $5 \mathrm{mg} / \mathrm{L}$, and water temperature and $\mathrm{pH}$ were maintained at $27 \pm 2^{\circ} \mathrm{C}$ and $7.7 \pm 0.2$, respectively. The feeding experiment was conducted at Binhai Aquaculture Station (Shanghai, China).

\section{Sample Collection And Analysis}

\section{Growth performance and physical indices}

When the feeding trial ended, all fish were starved for $24 \mathrm{~h}$, and measured total final body weight to calculate weight gain (WG) and feed conversion ratio (FCR). Three fish per cage were randomly selected and anesthetized with MS-222 (30 mg/L) to individually measure body weight, body length, liver weight, visceral weight and mesenteric lipid weight, then the indices of condition factor (K), hepato-somatic index (HSI), viscero-somatic index (VSI) and mesenteric lipid-somatic index (MSI) were calculated as follows:

Weight gain (WG, \%) = 100×[final weight- initial weight ]/initial weight

Feed conversion ratio $(\mathrm{FCR})=$ feed intake $/$ wet weight gain

Condition factor $\left(\mathrm{K}, \mathrm{g} / \mathrm{cm}^{3}\right)=100 \times\left[\right.$ body weight $(\mathrm{g}) /$ body length $\left.\left(\mathrm{cm}^{3}\right)\right]$ 
Viscero-somatic index $(\mathrm{VSI}, \%)=100 \times[$ visceral weight/body weight $]$

Hepato-somatic index $(\mathrm{HSI}, \%)=100 \times[$ liver weight /body weight]

Mesenteric lipid-somatic index (MSI, \%) = $100 \times$ Mesenteric fat weight $/$ final weight

\section{Water holding capacity of flesh}

Five blocks of flesh (about $3 \mathrm{~g}$ ) were sampled from the dorsal muscle of the left side of the body per fish to determine water-holding capacity (WHC) immediately as follows:

The first and second flesh sample (W1) was steaming in pot for 5 min or centrifuging at $3500 \mathrm{r} / \mathrm{min}$ for $10 \mathrm{~min}$, then wiped off the surface liquid and weighed (W2) to calculate steaming loss and centrifugal loss. The other three flesh sample (W1) at $4^{\circ} \mathrm{C}$ for 6,12 and $24 \mathrm{~h}$, respectively, then wiped off the surface liquid and weighed (W2) to calculate drip loss.

Steaming (centrifugal, drip) loss $(\%)=100 \times($ W1-W2 $) /$ W1

\section{Flesh And Diets Proximate Composition}

The rest of dorsal muscle was stored at $-20^{\circ} \mathrm{C}$ for the analysis of crude protein, crude lipid, crude ash, moisture, calcium, phosphorus, total collagen, heat-soluble collagen, free amino acids and fatty acid composition.

The proximate composition in flesh (moisture, crude lipid, crude protein and crude ash) was analyzed according to AOAC [27] methods described in our previous study [22]. The calcium, phosphorus content was determined by methylthymol blue colorimetry and phosphomolybdic acid colorimetry.

Total collagen content were calculated by multiplying the hydroxyproline content by 8 [22], and the hydroxyproline test kits were supplied by Nanjing Jiancheng Bioengineering Institute (Nanjing, China). Heat-soluble collagen was determined according to the method of Kong et al. [28]. Muscle sample (2 g) was homogenized with four times Ringer's solution $\left(0.86 \% \mathrm{NaCl}, 0.03 \% \mathrm{KCl}\right.$, and $\left.0.033 \% \mathrm{CaCl}_{2}\right)(10$ $000 \mathrm{rpm}, 1 \mathrm{~min})$, then the homogenate was heated at $77^{\circ} \mathrm{C}$ for $70 \mathrm{~min}$ and centrifuged $(12000 \mathrm{r} / \mathrm{min})$ for $30 \mathrm{~min}$ at $4{ }^{\circ} \mathrm{C}$. The extraction was repeated twice with supernatants combined. The collagen content of supernatants was measured as heat-soluble collagen.

Heat-insoluble collagen $=$ Total collagen - Heat-soluble collagen

For determination of free amino acid in muscle, samples were homogenized with 30 volumes of extract liquid (Methanol:water $=4: 1$ ) and centrifuged at $12000 \mathrm{r} / \mathrm{min}$ and $4{ }^{\circ} \mathrm{C}$ for $30 \mathrm{~min}$. The supernatants were analyzed using Ultra Performance Liquid Chromatography, UPLC (Waters Acquity, USA). The fatty acids 
composition of the muscle was determined with Boron trifluoride method according to the description of Zuo et al. [29] with GC-MS (7890B gas chromatograph- mass spectrometer, Agilents Technologies, USA).

\section{Antioxidant Capacity Of Flesh}

The muscle samples were thawed at $4{ }^{\circ} \mathrm{C}$, and then homogenized with four times ice-cold distilled water at $4{ }^{\circ} \mathrm{C}$ and centrifuged for $10 \mathrm{~min}(6000 \mathrm{r} / \mathrm{min})$. The supernatant was preserved at $4{ }^{\circ} \mathrm{C}$, and determined antioxidation index in $24 \mathrm{hr}$. Lactic acid (LC), malondialdehyde (MDA), protein carbonyl (PC), catalase (CAT), superoxide dismutase (SOD) and glutathione peroxidase (GSH-Px) were measured by kits (Shanghai Haling Biotechnology Co., Ltd, Shanghai, China)

\section{The Histology Of Flesh}

Muscle samples were immersed in $4 \%$ methanol solution for at least $48 \mathrm{hr}$. The tissue was dehydrated, paraffin-embedded, sectioned $(8 \mu \mathrm{m})$, stained (Picrosirius Red) and sealed with a neutral gum. The collagen distribution in flesh was observed using an imaging microscope (Nikon YS100).

\section{Digestive Enzyme Activity}

The anterior intestine was sampled from three fish per cage after they were dissected on ice, and then stored at $-80{ }^{\circ} \mathrm{C}$ until use. The $2.0 \mathrm{~g}$ samples were thawed at $4{ }^{\circ} \mathrm{C}$, and then homogenized with $8.0 \mathrm{ml}$ icecold distilled water at $4{ }^{\circ} \mathrm{C}$ and centrifuged for $10 \mathrm{~min}(6000 \mathrm{r} / \mathrm{min})$. The supernatant was collected and preserved at $4{ }^{\circ} \mathrm{C}$ until the use in $24 \mathrm{hr}$.

The measurement of amylase activity and soluble protein concentration were used by kits (Nanjing Jiancheng Bioengineering Institute) with iodine-starch colorimetric method and Coomassie brilliant blue method, respectively, and protease activity was analyzed by Folin-Ciocalteu method. The methods were referred to the description of Yang et al. [30].

\section{Digestibility}

After the sampling, all fish continued to keep their original feeds for one week, then the intact faeces was siphoned $2 \mathrm{hr}$ after feeding and stored at $-20^{\circ} \mathrm{C}$ for analysis. Yttrium contents in diets and faeces were analyzed using inductively coupled plasma (ICP) emission spectroscopy (Vista MPX; Varian). Faeces protein was measured as the above method (2.2.3). Apparent digestibility coefficient (ADC) of dry matter (DM) and crude protein (CP) was calculated as follows:

$\mathrm{ADC}$ of $\mathrm{DM}=\left[1-\right.$ Dietary $\mathrm{Y}_{2} \mathrm{O}_{3} /$ Faecal $\left._{2} \mathrm{O}_{3}\right] \times 100 \%$

$\mathrm{ADC}$ of $\mathrm{CP}=\left[1-\left(\right.\right.$ Faecal CP/Dietary $\mathrm{CP} \times$ Dietary $\mathrm{Y}_{2} \mathrm{O}_{3} /$ FaecalY $\left.\left._{2} \mathrm{O}_{3}\right)\right] \times 100 \%$ 


\section{Real time quantitative PCR analysis of gene expression in flesh}

Total RNA was isolated from muscle samples using an RNAiso Plus Kit (Takara, Dalian, China) and assessed by agarose gel electrophoresis and by spectrophotometric analysis. Subsequently, cDNA synthesis was performed using the PrimeScriptTM RT reagent Kit (Takara, Dalian, China), and then was stored at $-80^{\circ} \mathrm{C}$ until use. Based on the sequence of grass carp 18S (EU047719.1) and type $\nabla$ collagen (COL1A1, COL1A2), matrix metalloproteinase-2 (MMP-2) and matrix metalloproteinase-9 (MMP-9) in GenBank, and the cloned lysine oxidase (LOX) and proline hydroxylase (PHD) sequence of full length CDNA (they will be published separately) in our laboratory, the PCR primers were designed (Table 3). All real-time quantitative PCR analysis was performed using the SYBR® Premix Ex Taq (Perfect Real-Time) kit (TaKaRa) according to the manufacturer's instructions. The total reaction volume was $20 \mu \mathrm{l}$, containing $10 \mu$ SYBR ${ }^{\circledR}$ Premix Ex Taq ${ }^{\text {TM }}$ (Tli RNaseH Plus), $0.5 \mu$ l upstream primer, $0.5 \mu l$ downstream primer, $1 \mu \mathrm{l}$ cDNA template and $8 \mu \mathrm{ddd}_{2} \mathrm{O}$. The thermocycling conditions of real-time PCR were presented as follows: denaturing at $95^{\circ} \mathrm{C}$ for $3 \mathrm{~min}$ and 39 cycles of denaturing at $95^{\circ} \mathrm{C}$ for $5 \mathrm{~s}$, annealing at $60{ }^{\circ} \mathrm{C}$ for $10 \mathrm{~s}$ and extension at $72{ }^{\circ} \mathrm{C}$ for $30 \mathrm{~s}$, then the melting curve was created after the extension. The expression results of COL1A1, COL1A2, PHD, LOX, MMP-2 and MMP-9 in flesh was calculated using the $2^{-\triangle \Delta \mathrm{Ct}}$ method. 
Table 3

The primer for real-time PCR

\begin{tabular}{|lll|}
\hline Primer name & Sequence from $\mathbf{5}^{\prime}$ to $\mathbf{3}^{\prime}$ & usage \\
\hline 18srRNA-F & GGAATGAGCGTATCCTAAACCC & qRT-PCR \\
18srRNA-R & CTCCCGAGATCCAACTACAAGC & qRT-PCR \\
COL1A1-F & ACGCACACAAACAATCTCAAGT & qRT-PCR \\
COL1A1-R & GCATGGGGCAAGACAGTCA & qRT-PCR \\
COL1A2-F & ACTCCGATAGAGCCCAGCTT & qRT-PCR \\
COL1A2-R & ACATTGGTGGCGCAGATCA & qRT-PCR \\
\hline LOX-F & GTTATCAGGTGGCGATGGAG & qRT-PCR \\
\hline LOX-R & GTAGACTCGTATGGGTTGTAAGG & qRT-PCR \\
\hline PHD-F & CTCGAAACCCAACGGACAGA & qRT-PCR \\
\hline PHD-R & AGCTGTCCGTCTGTAAAGCC & qRT-PCR \\
\hline MMP2-F & GAGCTGTGGACATTAGGAGAAG & qRT-PCR \\
\hline MMP2-R & GAACAAGAGCTCATGAGGACAG & qRT-PCR \\
\hline MMP9-F & ACTTGGAGTTGTGGCTTTTC & qRT-PCR \\
\hline MMP9-R & AGGGCTCTGTCATCAGGTTA & qRT-PCR \\
\hline
\end{tabular}

\section{Statistical analysis}

The experimental data were carried out using SPSS 22.0 software, and presented as the mean \pm standard deviation (SD). All data were subjected to a one-way analysis of variance (ANOVA), and combined with Duncan's multiple range test to identify the differences among treatments. The significance level for differences was determined at $P<0.05$.

\section{Results}

\section{Growth performance and physical indices}

During the feeding period, no mortality was recorded. Compared to the control, WG was increased by $4.22 \%(P<0.05)$, and FCR was decreased by $0.07(P<0.05)$ by the ELE supplementation in diet, but the growth performance was not significantly affected by dietary EBE $(P>0.05)$. $\mathrm{HSI}, \mathrm{VSI}, \mathrm{MSI}, \mathrm{K}$ and survival showed no significant differences among all the treatments $(P>0.05)$ (Table 4). 
Table 4

Growth performance and physical indices of grass carp fed Eucommia extracts diets

\begin{tabular}{|c|c|c|c|}
\hline Parameters & Control & EBE & ELE \\
\hline IBW (g) & $59.67 \pm 0.32$ & $59.67 \pm 0.38$ & $59.67 \pm 0.65$ \\
\hline FBW (g) & $229.04 \pm 1.25^{\mathrm{a}}$ & $229.98 \pm 2.51^{a}$ & $236.18 \pm 2.87^{b}$ \\
\hline WG (\%) & $283.86 \pm 2.09^{a}$ & $285.44 \pm 4.19^{a}$ & $295.84 \pm 4.82^{b}$ \\
\hline FCR & $1.73 \pm 0.02 a$ & $1.72 \pm 0.03 a$ & $1.66 \pm 0.02 b$ \\
\hline $\mathrm{K}\left(\mathrm{g} / \mathrm{cm}^{3}\right)$ & $1.83 \pm 0.05$ & $1.81 \pm 0.04$ & $1.82 \pm 0.04$ \\
\hline VSI (\%) & $8.46 \pm 0.34$ & $8.32 \pm 0.44$ & $7.94 \pm 0.44$ \\
\hline HSI (\%) & $1.88 \pm 0.10$ & $1.82 \pm 0.07$ & $1.82 \pm 0.11$ \\
\hline MSI (\%) & $2.14 \pm 0.08$ & $2.04 \pm 0.10$ & $2.06 \pm 0.07$ \\
\hline Survival (\%) & 100.00 & 100.00 & 100.00 \\
\hline \multicolumn{4}{|c|}{$\begin{array}{l}\text { Values in the same row with different superscripts alphabets indicate significant differences }(p<0.05) \\
\text {. }\end{array}$} \\
\hline \multicolumn{4}{|c|}{$\begin{array}{l}\text { IBW, initial body weight (g); FBW, final body weight (g); WG, weight gain (\%); FCR, feed conversion } \\
\text { ratio; HSI, hepato-somatic index }(\%) \text {; VSI, viscero-somatic index }(\%) ; \text { MSI, mesenteric lipid-somatic } \\
\text { index }(\%) \text {; K, condition factor }\left(\mathrm{g} / \mathrm{cm}^{3}\right) \text {. }\end{array}$} \\
\hline
\end{tabular}

\section{Muscle Composition}

In Table 5, there were no significant differences in the contents of muscle moisture, crude lipid, crude protein, crude ash and phosphorus among all the groups $(P>0.05)$, but dietary ELE significantly increased the contents of calcium, total collagen and heat-insoluble collage when compared to the control $(P<0.05)$. 
Table 5

Proximate composition in muscle of grass carp fed Eucommia extracts diets (g/kg, wet weight)

\begin{tabular}{|llll|}
\hline Parameters & Control & EBE & ELE \\
\hline Moisture & $775.98 \pm 8.94$ & $777.20 \pm 5.87$ & $775.60 \pm 9.85$ \\
\hline Crude ash & $11.83 \pm 0.21$ & $11.73 \pm 0.15$ & $12.10 \pm 0.32$ \\
\hline Crude protein & $194.90 \pm 2.08$ & $195.65 \pm 1.34$ & $196.87 \pm 3.40$ \\
\hline Crude lipid & $12.80 \pm 0.85$ & $12.70 \pm 0.56$ & $12.17 \pm 1.89$ \\
\hline$P$ & $3.23 \pm 0.10$ & $3.04 \pm 0.14$ & $3.02 \pm 0.15$ \\
\hline Ca & $1.96 \pm 0.20^{\text {a }}$ & $2.11 \pm 0.27^{\text {ab }}$ & $2.38 \pm 0.12^{\mathrm{b}}$ \\
\hline T collagen & $3.10 \pm 0.19^{\mathrm{a}}$ & $3.09 \pm 0.15^{\mathrm{a}}$ & $3.41 \pm 0.16^{\mathrm{b}}$ \\
\hline HS collagen & $0.43 \pm 0.03$ & $0.43 \pm 0.02$ & $0.40 \pm 0.03$ \\
\hline HIS collagen & $2.67 \pm 0.13^{\mathrm{a}}$ & $2.66 \pm 0.17^{\mathrm{a}}$ & $3.01 \pm 0.12^{\mathrm{b}}$ \\
\hline \begin{tabular}{l} 
Values in the same row with different superscripts alphabets indicate significant differences $(p<0.05)$ \\
\hline$\cdot$
\end{tabular} & & \\
\hline $\begin{array}{l}\text { T collagen: total collagen; HS collagen: heat-soluble collagen; HIS collagen: heat-insoluble collagen; } \\
\text { Ca: calcium; P: phosphorus. }\end{array}$ \\
\hline
\end{tabular}

In Fig. 1, the red area relected the distribution of collagen in muscle, and the collagen in muscle mainly distributed in the endomysium (EM) and perimysium (PM). The ELE group rather than EBE group showed significantly larger red area (collagen) than the control group.

\section{Digestibility and digestive enzyme activity}

The dry matter and protein digestibility, the activity of protease and amylase in ELE group, but not in EBE group, were significantly higher than those of the control group $(P<0.05)$ (Table 6). 
Table 6

The nutrient digestibility and digestive enzyme activities of grass carp fed Eucommia extracts diets

\begin{tabular}{|lccl|}
\hline Parameters & Control & EBE & ELE \\
\hline Dry matter digestibility (\%) & $57.28 \pm 0.52^{\mathrm{a}}$ & $57.75 \pm 1.17^{\mathrm{a}}$ & $59.73 \pm 1.09^{\mathrm{b}}$ \\
\hline Crude protein digestibility (\%) & $84.69 \pm 0.76^{\mathrm{a}}$ & $85.17 \pm 0.45^{\mathrm{ab}}$ & $86.33 \pm 0.63^{\mathrm{b}}$ \\
\hline Amylase activity (U/mg prot) & $4.81 \pm 0.33^{\mathrm{a}}$ & $5.38 \pm 0.26^{\mathrm{ab}}$ & $6.50 \pm 0.39^{\mathrm{b}}$ \\
\hline Protease activity (U/mg prot) & $77.06 \pm 4.34^{\mathrm{a}}$ & $80.17 \pm 5.90^{\mathrm{ab}}$ & $86.65 \pm 4.55^{\mathrm{b}}$ \\
\hline Values in the same row with different superscripts alphabets indicate significant differences $(p<0.05)$ \\
\hline
\end{tabular}

\section{Water holding capacity and antioxidant capacity of flesh}

In Table 7, the supplementation of EBE and ELE in diets significantly decreased the flesh steaming loss, centrifugal loss and the contents of LC, PC and MDA, while increased the activity of SOD and GSH-Px ( $P$ $<0.05)$. No significant difference was found in CAT activity among the three groups $(P>0.05)$. 
Table 7

The flesh water-holding capacity and antioxidant parameters of grass carp fed Eucommia extracts diets

\begin{tabular}{|c|c|c|c|}
\hline Parameters & Control & EBE & ELE \\
\hline Steaming loss (\%) & $11.29 \pm 0.62^{\mathrm{a}}$ & $7.61 \pm 0.85^{b}$ & $8.45 \pm 0.75^{b}$ \\
\hline Centrifugal loss (\%) & $8.71 \pm 0.52^{\mathrm{a}}$ & $6.79 \pm 0.60^{b}$ & $7.11 \pm 0.73^{b}$ \\
\hline Drip loss ${ }^{6 \mathrm{~h}}(\%)$ & $13.99 \pm 0.56$ & $13.86 \pm 1.24$ & $13.09 \pm 0.75$ \\
\hline Drip loss ${ }^{12 h}(\%)$ & $22.53 \pm 2.54$ & $22.01 \pm 0.52$ & $22.06 \pm 1.53$ \\
\hline Drip loss ${ }^{24 h}(\%)$ & $37.02 \pm 1.18^{a}$ & $32.20 \pm 1.55^{b}$ & $31.88 \pm 0.97^{b}$ \\
\hline LC $(\mu \mathrm{mol} / \mathrm{g})$ & $6.49 \pm 0.40^{\mathrm{a}}$ & $5.97 \pm 0.19^{b}$ & $5.98 \pm 0.08^{b}$ \\
\hline $\mathrm{PC}(\mu \mathrm{mol} / \mathrm{g}$ prot $)$ & $1.05 \pm 0.05^{\mathrm{a}}$ & $0.98 \pm 0.01^{b}$ & $0.96 \pm 0.02^{b}$ \\
\hline MDA (nmol/g prot) & $16.24 \pm 1.01^{\mathrm{a}}$ & $13.40 \pm 1.56^{b}$ & $12.82 \pm 0.47^{b}$ \\
\hline $\operatorname{SOD}(\mu / \mathrm{g}$ prot $)$ & $522.4 \pm 17.7^{a}$ & $600.3 \pm 33.8^{b}$ & $607.6 \pm 23.1^{b}$ \\
\hline CAT ( $\mu / g$ prot) & $1673.5 \pm 21.3$ & $1672.2 \pm 13.3$ & $1685.4 \pm 10.7$ \\
\hline GSH-Px (nmol/min/g prot) & $2744.5 \pm 151.0^{\mathrm{a}}$ & $3424.7 \pm 445.3^{b}$ & $3344.8 \pm 137.1^{b}$ \\
\hline \multicolumn{4}{|c|}{$\begin{array}{l}\text { Values in the same row with different superscripts alphabets indicate significant differences }(p<0.05) \\
.\end{array}$} \\
\hline \multicolumn{4}{|c|}{$\begin{array}{l}\text { lactic acid (LC), malondialdehyde (MDA), protein carbonyl (PC), catalase(CAT), superoxide dismutase } \\
\text { (SOD), glutathione peroxidase (GSH-Px) }\end{array}$} \\
\hline
\end{tabular}

\section{Free Amino Acids In Muscle}

In Table 8, a total of 17 free amino acids were detected in the muscle. Compared to the control, dietary ELE significantly increased Gly, Ala, delicious amino acids (DAAs) and total free amino acids (TFAAs), while decreased Cys in flesh $(P<0.05)$. Thr, Leu and Ser were significantly higher in EBE group, while Arg and Cys were lower than those of the control $(P<0.05)$. 
Table 8

Muscle free amino acid of grass carp fed Eucommia extracts diets (mg/kg, wet weight)

\begin{tabular}{|c|c|c|c|}
\hline Parameters & Control & EBE & ELE \\
\hline Aspt & $8.07 \pm 1.01$ & $8.03 \pm 2.70$ & $7.17 \pm 3.22$ \\
\hline Glut & $28.87 \pm 2.66$ & $28.03 \pm 3.11$ & $28.6 \pm 2.50$ \\
\hline Glyt & $125.67 \pm 9.25^{a}$ & $139.67 \pm 6.65^{a}$ & $178.70 \pm 23.9^{b}$ \\
\hline Alat & $73.17 \pm 5.71^{a}$ & $82.63 \pm 4.29^{\mathrm{ab}}$ & $91.20 \pm 8.40^{b}$ \\
\hline Cys & $10.40 \pm 0.61^{a}$ & $4.87 \pm 1.77^{b}$ & $3.37 \pm 0.75^{b}$ \\
\hline Tyr & $11.60 \pm 0.53$ & $12.27 \pm 0.90$ & $10.77 \pm 2.0$ \\
\hline Pro & $138.40 \pm 7.89$ & $128.13 \pm 8.01$ & $137.27 \pm 3.49$ \\
\hline Ser & $9.83 \pm 1.08^{a}$ & $14.27 \pm 0.40^{b}$ & $11.97 \pm 1.68^{\mathrm{ab}}$ \\
\hline Val & $9.93 \pm 1.02$ & $10.36 \pm 0.70$ & $9.90 \pm 0.76$ \\
\hline Met & $4.70 \pm 1.45$ & $3.50 \pm 1.08$ & $3.93 \pm 0.71$ \\
\hline lle & $5.17 \pm 1.03$ & $6.83 \pm 1.51$ & $4.63 \pm 1.57$ \\
\hline Leu & $7.73 \pm 0.76^{\mathrm{a}}$ & $10.87 \pm 1.86^{b}$ & $7.90 \pm 1.13^{\mathrm{a}}$ \\
\hline Thr & $99.27 \pm 16.83^{a}$ & $111.40 \pm 6.83^{b}$ & $95.40 \pm 10.96^{a}$ \\
\hline His & $335.57 \pm 7.62$ & $334.90 \pm 9.57$ & $333.87 \pm 9.66$ \\
\hline Lys & $30.77 \pm 3.68$ & $29.63 \pm 3.88$ & $31.40 \pm 5.15$ \\
\hline Arg & $32.73 \pm 2.40^{a}$ & $19.00 \pm 1.47^{b}$ & $36.77 \pm 4.89^{a}$ \\
\hline Phe & $7.13 \pm 1.00$ & $7.53 \pm 2.19$ & $6.37 \pm 1.04$ \\
\hline DAAs & $235.80 \pm 9.47^{a}$ & $258.30 \pm 3.68^{\mathrm{ab}}$ & $305.70 \pm 30.00^{b}$ \\
\hline TFAAs & $938.97 \pm 12.07^{a}$ & $951.83 \pm 16.20^{\mathrm{ab}}$ & $986.01 \pm 26.14^{b}$ \\
\hline \multicolumn{4}{|c|}{$\begin{array}{l}\text { Values in the same row with different superscripts alphabets indicate significant differences }(p<0.05) \\
\text {. }\end{array}$} \\
\hline DAAs, delicic & no acids $(\dagger)$; TFAA & ee amino acids & \\
\hline
\end{tabular}

\section{Fatty Acids Composition In Muscle}


As shown in Table 9, a total of 14 fatty acid were detected in the muscle. There were no significant differences in saturated fatty acids (SFAs), monounsaturated fatty acids (MUFAs) and polyunsaturated fatty acids (PUFAs) among all the treatments $(P>0.05)$, but the supplementation of EBE and ELE significantly increased DPA, DHA, n-3PUFAs and n-3/n-6 ratio in flesh $(P<0.05)$.

Table 9

Muscle fatty acid composition of grass carp fed Eucommia extracts diets (percentage of fatty acids, \%)

\begin{tabular}{|c|c|c|c|}
\hline Parameters & Control & EBE & ELE \\
\hline $\mathrm{C} 14: 0$ & $1.23 \pm 0.02$ & $1.31 \pm 0.07$ & $1.23 \pm 0.12$ \\
\hline C16:0 & $14.27 \pm 0.27$ & $14.38 \pm 0.22$ & $14.38 \pm 0.61$ \\
\hline C170 & $0.35 \pm 0.05$ & $0.38 \pm 0.08$ & $0.37 \pm 0.11$ \\
\hline C18:0 & $8.92 \pm 0.37$ & $8.59 \pm 0.11$ & $8.08 \pm 0.29$ \\
\hline SFAs & $24.75 \pm 0.48$ & $24.67 \pm 0.13$ & $24.06 \pm 1.08$ \\
\hline $\mathrm{C} 16: 1$ & $2.01 \pm 0.10$ & $2.16 \pm 0.08$ & $2.23 \pm 0.05$ \\
\hline C18:1 & $32.39 \pm 0.66$ & $30.25 \pm 1.22$ & $31.55 \pm 1.54$ \\
\hline C20:1 & $1.12 \pm 0.06$ & $1.15 \pm 0.01$ & $1.19 \pm 0.07$ \\
\hline MUFAs & $33.52 \pm 0.64$ & $32.41 \pm 1.22$ & $32.73 \pm 1.5$ \\
\hline C18:2 & $25.36 \pm 1.33$ & $24.56 \pm 0.69$ & $24.16 \pm 1.35$ \\
\hline $\mathrm{C} 20: 2$ & $0.97 \pm 0.03$ & $1.03 \pm 0.03$ & $1.03 \pm 0.06$ \\
\hline C20:3 & $1.33 \pm 0.16$ & $1.43 \pm 0.08$ & $1.50 \pm 0.17$ \\
\hline ARA & $6.59 \pm 0.86$ & $6.48 \pm 1.02$ & $6.52 \pm 1.27$ \\
\hline n-6PUFA & $34.26 \pm 0.51$ & $33.50 \pm 0.65$ & $33.21 \pm 0.55$ \\
\hline EPA & $0.42 \pm 0.08$ & $0.47 \pm 0.05$ & $0.52 \pm 0.10$ \\
\hline DPA & $2.31 \pm 0.43^{a}$ & $3.33 \pm 0.63^{b}$ & $3.63 \pm 0.41^{b}$ \\
\hline DHA & $2.74 \pm 0.51^{\mathrm{a}}$ & $3.44 \pm 0.19^{b}$ & $3.60 \pm 0.08^{b}$ \\
\hline n-3PUFAs & $5.48 \pm 0.97^{a}$ & $7.23 \pm 0.63^{b}$ & $7.75 \pm 0.4^{\mathrm{b}}$ \\
\hline PUFAs & $39.73 \pm 1.09$ & $40.73 \pm 1.21$ & $40.97 \pm 0.65$ \\
\hline$n-3 / n-6$ & $0.16 \pm 0.03^{a}$ & $0.21 \pm 0.02^{b}$ & $0.23 \pm 0.01^{b}$ \\
\hline
\end{tabular}

Values in the same row with different superscripts alphabets indicate significant differences $(p<0.05)$

SFAs, saturated fatty acids; MUFAs, monounsaturated saturated fatty acids; PUFAs, polyunsaturated fatty acids 


\section{Gene Expression In Muscle}

As shown in Fig. 2, the gene expression levels of COL1A1DCOL1A2 PPHD and LOX in flesh were significantly increased, and MMP-2, MMP-9 expression was decreased by dietary ELE $(P<0.05)$, while these genes showed no significant differences between EBE group and control group $(P>0.05)$.

\section{Discussion}

\section{Effects of Eucommia extracts on the growth performance}

In land animals, the supplementation of $0.08 \%$ ELE (containing total phenolic acid $542.9 \mathrm{~g} / \mathrm{kg}$, total flavonoids $64.4 \mathrm{~g} / \mathrm{kg}$ ) in diet increased the average daily gain (ADG) of pig by $18.6 \%$ and decreased FCR by 0.49 [19]. Zhao et al. [18] also reported that dietary ELE (containing $820 \mathrm{~g} / \mathrm{kg}$ chlorogenic acid) $(0.1 \%)$ significantly increased ADG (+11.39\%) and decreased FCR $(-0.15)$ of chicken. In grass carp [31] and crucian carp [13], the WG was also reported to be increased $(+8.57 \%,+12.9 \%)$ by the supplementation of $0.15 \%$ ELE (containing $50 \mathrm{~g} / \mathrm{kg}$ chlorogenic acid, $80 \mathrm{~g} / \mathrm{kg}$ total flavonoids and $200 \mathrm{~g} / \mathrm{kg}$ crude polysaccharide). In the present study, the WG of grass carp was increased by $4.22 \%$ and FCR decreased by $0.07(P<0.05)$ by the supplementation of $4 \mathrm{~g} / \mathrm{kg}$ ELE, which was consistent with the above results. However, the present inclusion level of ELE was higher than that in others studies, which may be related to the lower active compounds content in this extract (Table 1).

The improvement of intestinal digestive enzymes and nutrients utilization may be directly related to the promote growth-promoting effect of ELE. It has been reported that intestinal digestive enzymes and nutrient digestibility were significantly increased by dietary ELE, therefore improving growth performance of crucian carp [13] and chicken [32]. In general, the intestinal digestion and absorption is closely related to the intestinal microflora. In the study of Shi et al. [33], dietary ELE inhibited the pathogenic bacteria by promoting the growth of probiotics and balancing the intestinal floracommunity. Lv et al. [8] found that ELE reduced the number of intestinal Escherichia coli in chicken, which may be concerned with the active compounds such as phenolic acids, flavonoids and polysaccharides in ELE. Studies have shown that phenolic acids [34], flavonoids [35], and polysaccharides [36] inhibited the colonization of pathogenic bacteria in the intestines, increased the number of beneficial bacteria and enhanced the intestinal nutrient absorption. In grass carp, the EU active compounds such as chlorogenic acid [22], quercetin [23] and baicalein [37] have been reported to significantly promote the growth performance. Therefore, the growth improvement by dietary ELE is the combined effect of various active compounds.

However, the supplementation of EBE did not improve the growth of grass carp in this study. The similar result was also reported in rainbow trout that was fed diet containing water extract of Eucommia bark [38]. As shown in Table 1, the active compounds contents in EBE are lower than those of the ELE, which may be the major reason that the growth-promoting effect was observed in ELE diet rather than in EBE diet. If more EBE was supplemented, or the EBE contained higher concentration of active compounds, it would promote the growth performance of grass carp. In addition, the active compounds composition of 
EU bark was different from the leaf. Generally, barks contain more lignin and iridoids, while leaves contain more phenolic acids and flavonoids [39]. Previous studies in our laboratory have shown that dietary phenolic acids (chlorogenic acids) [9] and flavonoids (quercetin) [23] produced more positive effects on growth of grass carp than iridoids (geniposide and geniposidic acid) did [24-25].

\section{Effects of Eucommia extracts on the flesh quality}

Water-holding capacity (WHC) is directly related to the flesh quality, and it is generally evaluated by steaming loss, centrifugal loss and drip loss [40]. The supplementation of both Eucommia extracts significantly promoted the flesh WHC by decreasing steaming loss, centrifugal loss and drip loss in this study, and the similar results were also reported in pig [41], chicken [18] and lamb [16]. The improvement of flesh WHC mainly resulted from the reduction of oxidative damage, thus promoting the structural integrity of muscle tissue [42]. In fish, MDA and PC contents are widely used for evaluating the oxidative damage of lipid and protein [43]. Generally, the oxidation of protein and lipid is related to the increased levels of superoxide free radicals $\left(\mathrm{O}^{2-}\right)$ and hydroxyl free radicals $\left(\mathrm{OH}^{-}\right)$in the body, while SOD, CAT, and GSH-Px are non-enzymatic antioxidants that can clear $\mathrm{O}^{2-}$ and $\mathrm{OH}^{-}$, and play an important role in the self-protection system of organisms [44]. In this study, the MDA and PC contents in EBE and ELE groups were significantly decreased, and SOD and GSH-PX activities were significantly increased. Similarly, Eucommia leaf extracts was also reported to improve the muscle antioxidant capability in chicken [18] and lamb[18]. Zhao et al. [45] reported that flesh WHC is negatively correlated with MDA and PC levels, and positively correlated with SOD and GSH-PX activities, and the similar results was also found in the present study. In addition, the lactic acid content of muscle is another important factor affecting the flesh WHC. After the slaughtering, muscle metabolism mode was changed from aerobic to anaerobic status. The anaerobic respiration of muscle glycogen generated a large amount of lactic acid, which decreased muscle $\mathrm{pH}$ and caused protein denaturation, thereby affecting flesh WHC [46]. In the current study, Eucommia extracts significantly decreased the lactic acid content in flesh of grass carp. Maybe Eucommia extracts promote the aerobic metabolism in muscle, and the similar results have been found in chicken [18] and pig [19]. Fatty acid composition is also an important indicator of flesh quality. As an important part of unsaturated fatty acids, n-3PUFAs play important roles in preventing cardiovascular and cerebrovascular diseases, and in lowering serum lipid, blood pressure and inflammation [47-48]. When used for the nutrition evaluation of flesh, the ratio of $n-3 / n-6$ PUFA may be more important than the content of n-3PUFAs or n-6PUFAs [1]. In the current study, dietary EBE and ELE increased DPA, DHA, the n3 PUFAs and n-3/n-6 ratio in flesh, which may be related to the active compounds such as phenolic acids and flavonoids. The studies of Andrés et al. [49] and Starčević et al. [50] have shown that phenolic acids (gallic acid) and flavonoids (quercetin) increased the $n-3 / n-6$ ratio in lamb and chicken, respectively. The changes in fatty acid composition may result from it's the lipid intake, transport, metabolism and storage processes, and the modulating mechanism of Eucommia extracts for fatty acids needs a further study in the future. 
Free amino acids, especially delicious amino acids, are the major flavor substance in the flesh of fish. In the study, the free delicious amino acid and total free amino acid contents in ELE group were significantly increased, especially glycine and alanine. The increased free amino acid in muscle could provide sufficient raw materials for the body to synthesize protein [51]. So, it is speculated that dietary ELE promoted the protein transport and metabolism, then increased the content of free amino acids including delicious amino acids, which needs further study.

As the most abundant metal element in the body, calcium is widely involved in various physiological processes such as muscle contraction, neurotransmitter synthesis and release [52], and it is also closely related to the muscle fiber development [52], muscle fiber type [53] and muscle hardness [54]. In the study of Oikawa et al. [55], ELE was reported to promote calcium accumulation in human osteoblasts through calcium signaling pathways. Therefore, the increased calcium content in flesh by dietary ELE was also found in the present study. Maybe calcium signaling pathway induced by ELE modulate the calcium accumulation in muscle.

\section{Effects of Eucommia extracts on collagen-related genes expression}

As the major component of connective tissues, collagen influences the functional and structural properties of muscle, and makes a great contribution to the adhesion and tensile strength of muscle [56]. In fish, it has been reported that the collagen content was positively correlated with flesh hardness [57]. Dietary ELE significantly increased the flesh collagen in crucian carp [13] and shrimp [15]. Collagen can be divided into two groups, soluble and insoluble collagen. Sun et al. [9] found that dietary EU (2\%) increased alkaline-insoluble collagen rather than the soluble collagen in muscle of grass carp. The similar results were also found in the present study with the increased total collagen and heat-insoluble collagen in flesh, which indicated that the increased total collagen in muscle mainly comes from the insoluble collagen, the structural part of collagen in muscle.

The collagen in fish muscle was mainly type I collagen, containing two a1 chains (COL1A1) and one a2 chain (COL1A2). The biosynthesis of collagen begins from the transcription of COL1A1 and COL1A2. Guan et al. [58] once reported that ELE promoted the expression of COL1A1 gene in osteoblast cell of rats. In grass carp, Xu et al. [14] found that dietary EU (bark) significantly increased the expression of COL1A1 and COL1A2 in muscle and skin. In the present study, ELE also promoted the mRNA expression of COL1A1 and COL1A2 in muscle. The active compounds in EU such as chlorogenic acid, geniposide and geniposidic acid may be involved in the up-regulation of genes, which has been proved in the previous studies in grass carp, where COL1A1 expression in muscle was promoted by the three active compounds supplementation in diets [22].

The biosynthesis of collagen involves a series of processes, including the transcription and translation of genes, the post-translational modification and covalent cross-linking. Proline hydroxylase (PHD) is an 
important hydroxylase for post-translational modification, and it can increase the stability of intermolecular hydrogen bonds. If the hydroxylation was incomplete, a triple helix cannot be formed, which affects the secretion of procollagen molecules outside the cell [59]. Lysine oxidase (LOX) is the only enzyme involved in covalent cross-linking, and the insufficient secretion will affect the elasticity and toughness of collagen [60]. At present, the effects of dietary nutrients on PHD and LOX gene expression have not been reported in aquatic animals. We cloned the full-length sequences of PHD and LOX genes (it will be published in another paper) for the first time, and found that dietary ELE significantly increased the expression of LOX and PHD in grass carp muscle. In the future, we will continue investigating what active compounds in Eucommia extracts up-regulate the genes expression.

The decomposition process of collagen also affects the muscle collagen content. The major enzymes involved in collagen degradation are matrix metalloproteinases (MMPs). MMPs a are highly conserved metal ion-dependent enzymes, and they can degrade almost all components in extracellular matrix [61]. In fish, type I and V collagen are the two main types of collagen in muscle [62], and MMP-2 and MMP-9 showed a significant degradation effect on collagen, especially type I and V collagen [63]. In the study of Chen et al. [64] and Wang et al. [65], ELE decreased the mRNA expression of MMP-2 in endothelial cells and MMP-9 in ankle of rat. Therefore, the increased collagen in flesh by dietary ELE is the combined results of increased synthesis and decreased decomposition of collagen.

\section{Conclusion}

In the present study, dietary ELE $(4 \mathrm{~g} / \mathrm{kg})$ promoted the growth performance and antioxidant capacity of grass carp, and improved the flesh quality by increasing the expression of collagen synthesis- related genes and decreasing the expression of collagen degradation-related genes.

\section{Declarations}

\section{Availability of data and materials}

All data generated or analyzed during this study are included in this published article.

\section{Acknowledgements}

The authors acknowledge the National Natural Science Foundation of China for financial assistance.

\section{Funding}

This study was supported by the National Natural Science Foundation of China (grant no. 31772825).

\section{Author information}

Hang Yang and Sumei Tan are the Co-first author 


\section{Affiliations}

National Demonstration Center for Experimental Fisheries Science Education, Shanghai Ocean University, Shanghai 201306, People's Republic of China.

Centre for Research on Environmental Ecology and Fish Nutrition (CREEFN) of the Ministry of Agriculture, Shanghai Ocean University, Shanghai 201306, People's Republic of China.

Shanghai Collaborative Innovation for Aquatic Animal Genetics and Breeding, Shanghai Ocean University, Shanghai 201306, People's Republic of China

\section{Contributions}

Hang Yang and Sumei Tan completed the experiment and prepared the manuscript. Xiaoqin Li, Zhen Xu and Zhuo Cheng carried out the growth experiment and analysed the samples. Xiangjun Leng designed the experiment and revised the manuscript.

\section{Corresponding author}

Correspondence to Xiangjun Leng

E-mail: xjleng@shou.edu.cn

Address: College of Fisheries and Life Science, Shanghai Ocean University, No. 999, Hucheng Ring Road, Lingang New City, Pudong New District, Shanghai, China.

\section{Ethics declarations}

\section{Ethics approval and consent to participate}

All the procedures were strictly carried out in accordance with the Regulations of the Experimental Animal Ethics Committee of Shanghai Ocean University and in compliance with regulations by Institutional Animal Care and Use Committee.

\section{Consent for publication}

Not applicable.

\section{Competing interests}

The authors declare that they have no competing interests.

\section{References}


1. Zhao H, Soufan O, Xia J, Tang R, Li L, Li D. Transcriptome and physiological analysis reveal alterations in muscle metabolisms and immune responses of grass carp (Ctenopharyngodon idellus) cultured at different stocking densities. Aquaculture. https://doi.org/10.1016/j.aquaculture.2019.01.003.

2. Beltrán JMG, Espinosa C, Guardiola FA, Esteban MÁ. In vitro effects of Origanum vulgare leaf extracts on gilthead seabream (Sparus aurata) leucocytes, cytotoxic, bactericidal and antioxidant activities. Fish Shellfish Immun. 2018. https://doi.org/10.1016/j.fsi.2018.05.005.

3. Hussain T, Tan BE, Liu G, Oladele OA, Rahu N, Tossou MC, Yin Y. Health-promoting properties of Eucommia ulmoides: a review. Evid-Based Compl Alt. 2016. https://doi.org/10.1155/2016/5202908.

4. Li S, Zhao M, Jiang T, Lv W, Gao S, Zhou Y, Miao Z. Growth performance and antioxidant status of growing rabbits fed on diets supplemented with Eucommia ulmoidesWorld Rabbit Sci, 2018. https://doi.org/10.4995/wrs.2018.7864.

5. Peng M, Wang Z, Peng S, Zhang M, Duan Y, Li F, et al. Dietary supplementation with the extract from Eucommia ulmoides leaves changed epithelial restitution and gut microbial community and composition of weanling piglets. PloS One. 2019. https://doi.org/10.1371/journal.pone.0223002.

6. Lee SD, Kim HY, Song YM, Jung HJ, Ji SY, Jang HD, et al. The effect of Eucommia ulmoides leaf supplementation on the growth performance, blood and meat quality parameters in growing and finishing pigs. Anim Sci J. 2009. https://doi.org/10.1111/j.1740-0929.2008.00593.x

7. Wang MQ, Du YI, Ye SS, Tao WI, Wang C. Effects of Duzhong (Eucommia ulmoides) on Growth Performance and Meat Quality in Broiler Chicks. J Anim Vet Adv. 2012. https://doi.org/10.3923 /javaa.2012.1385.1389.

8. Lv WX, He JH, Wang JH. Effects of Eucommia ulmoides extract on performance and intestinal microflora of broilers. Chinese J Anim Nutr. 2007(01):61-65.

9. Sun WT, Li XQ, Xu HB, Chen JN, Xu XY, Leng XJ. Effects of dietary chlorogenic acid on growth, flesh quality and serum biochemical indices of grass carp (Ctenopharyngodon idella). Aquacult Nutr. 2017 https://doi.org/10.1111/anu.12500.

10. Wang J, Xie J, Tu Z, Wei J, Pan W, Hu J, et al. Cloning and expression analysis of the nuclear factor erythroid 2-related factor 2 (Nrf2) gene of grass carp (Ctenopharyngodon idellus) and the dietary effect of Eucommia ulmoides on gene expression. Aquacult Fish. 2018a. https://doi.org/10.1016/j.aaf.2018.07.003.

11. Zhang B, Li C, Wang X, Zhou H, Mai K, He G. The effects of dietary Eucommia ulmoides Oliver on growth, feed utilization, antioxidant activity and immune responses of turbot (Scophthalmus maximus ). Aquacult Nutr. 2019b. https://doi.org/10.1111/anu.12862.

12. Tanimoto SY, Ikuma K, Takahashi S. Improvement in raw meat texture of cultured eel by feeding of Tochu leaf powder. Biosci Biotech Bioch. 1993;57:205-208.

13. Shi Y, Leng XJ, Li XQ, Li BS, Hu B. Effect of Du-zhong (Eucommia ulmoides Oliver) leaf extract on growth, serum non-specific immune response and meat quality of crucian carp. $J$ Zhejiang Univ. 2008;34:200-206. 
14. Xu XY, Li XQ, Sun WT, Jiang WB, Pan WQ, Wang JP, et al. Effects of dietary Eucommia ulmoides on growth, flesh quality, and collagen gene expression of grass carp. J Fish China, https://doi.org/10.11964/jfc.20170410810.

15. Liu B, Leng XJ, Li XQ, Li NS, Chai XQ. Effect of Eucommia ulmoides on growth, serum non-specific immunity, and muscle composition of Litopenaeus vannamei. J Fish Sci China. 2013;20:869-875.

16. Liu HW, Zhao JS, Li K, Deng W. Effects of chlorogenic acids-enriched extract from Eucommia ulmoides leaves on growth performance, stress response, antioxidant status and meat quality of lambs subjected or not to transport stress. Anim Feed Sci Tech. 2018. https://doi.org/10.1016/j.anifeedsci.2018.02.003.

17. Li YW, Jiang BY, Liu JS, Wang RJ, Wen HM, Ma MW. Effects of Eucommia ulmoides leaf extracts on growth performance,serum biochemical,immune and antioxidant indexes of meat rabbits. Chinese $\mathrm{J}$ Anim Nutr. 2019.

18. Zhao JS, Deng W, Liu HW. Effects of chlorogenic acid-enriched extract from Eucommia ulmoides leaf on performance, meat quality, oxidative stability, and fatty acid profile of meat in heat-stressed broilers. Poultry Sci. 2019b. https://doi.org/3382/ps/pez081.

19. Zhou Y, Ruan Z, Li XL, Mi SM, Jiang M, Liu WH, et al. Eucommia ulmoides Oliver leaf polyphenol supplementation improves meat quality and regulates myofiber type in finishing pigs. J Anim Sci. 2016. https://doi.org/2527/jas2015-9551.

20. Jiang S, Yang ZB, Huang LB, Yang WR, Song DP, Liu FX, et al. Effect of Illicium verum or Eucommia ulmoides leaf extracts on the anti-stress ability, and mRNA and protein expression of Nrf2 and TNF-a in Durocx LandracexYorkshire and Chinese native Licha-black nursery piglets. J Anim Physiol An N. 2019. https://doi.org/10.1111/jpn.13235.

21. Fishery Bureau, Ministry of Agriculture. China fishery statistical yearbook (25 pp.). Beijing: China Agriculture Press; 2019.

22. Sun WT, He M, Xu XY, Li XQ, Pan WQ, Leng XJ. Comparison study of three compounds in Eucommia ulmoides on growth, flesh quality of grass carp (Ctenopharyngodon idella). Aquacult Nutr. 2019. https://doi.org/10.1111/anu.12909.

23. Xu Z, Li X, Yang H, Liang G, Gao B, Leng, X. Dietary quercetin improved the growth, antioxidation, and flesh quality of grass carp (Ctenopharyngodon idella). J World Aquacult Soc. 2019. https://doi.org/ $10.1111 /$ jwas. 12663.

24. Sun WT, Li X, Xu H, Chen J, Xu X, Leng X. Effects of dietary geniposide on growth, flesh quality, and lipid metabolism of grass carp, Ctenopharyngodon idella. J World Aquacult Soc. 2017. https:// doi.org /10.1111/jwas.12412.

25. Sun WT, Xu XY, Li XQ, Pan WQ, Leng XJ. Effects of dietary geniposidic acid on growth performance, flesh quality and collagen gene expression of grass carp, Ctenopharyngodon idella. Aquacult Nutr. 2018. https://doi.org/10.1111/anu.12650.

26. Leng XJ, Meng XL, Li JL, Li XL, Hua, XM. Effect of Du-zhong (Eucommia ulmoides Oliver) leaf on growth, serum non-specific immune index and meat quality of grass carp. J Fish China. 2008. 
https://doi.org/3724/SP.J.00001.

27. Association of Official Analytical Chemists (AOAC). Official methods of analysis. 15th ed. Arlington: Association of official analytical chemists; 1990.

28. Kong F, Tang J, Lin M, Rasco B. Thermal effects on chicken and salmon muscles: Tenderness, cook loss, area shrinkage, collagen solubility and microstructure. LWT-Food Sci Technol. https://doi.org/ 10.1016/j.lwt.2007.07.020.

29. Zuo R, Ai Q, Mai K, Xu W, Wang J, Xu H, et al. Effects of dietary n-3 highly unsaturated fatty acids on growth, nonspecific immunity, expression of some immune related genes and disease resistance of large yellow croaker (Larmichthys crocea) following natural infestation of parasites (Cryptocaryon irritans). Fish Shellfish Immun. 2012. https://doi.org/10.1016/j.fsi.2011.11.005.

30. Yang H, Li X, Liang G, Xu Z, Leng XJ. Cork and guar gum supplementation enhanced the buoyancy of faeces, and protease supplementation alleviated the negative effects of dietary cork on growth and intestinal health of tilapia, Oreochromis niloticusx O. aureus. Aquacult Nutr. 2019. https://doi.org/1111/anu.12964.

31. Meng XL, Leng XJ, Li XQ, Lun F, Liu XM, Li BS, Li, JL. Effect of Eucommia ulmoides on growth and serum non-specific immune index of grass carp (Ctenopharyngodon idellus) fingerling. J Shanghai Fish Univ. 2007. https://doi.org/10.1007/978-3-540-78820-1_4.

32. Huang L, Ding XX, Feng J. Effects of Eucommia Ulmoides extract on Growth Performance and Nutrient Digestion and Utilization of Yellow Feather Broilers. Chinese J Anim Nutr. 2019. https://doi.org/ 10.19556/j.0258-7033.20190828-03.

33. Shi HS, Zhao X, Wang YJ, Li JL, Wang YN, Zhang Y, et al. Effect of aqueous extract of Eucommia ulmoides leaves on antimicrobial activity of Lactobacillus bulgaricus. West China J Pharm Sci. 2019;34:152-156.

34. Parkar SG, Stevenson DE, Skinner MA. The potential influence of fruit polyphenols on colonic microflora and human gut health. Int J Food Microbiol. 2008. https://doi.org/10.1016/j.ijfoodmicro.2008.03.017.

35. Serra A, Macià A, Romero MP, Reguant J, Ortega N, Motilva MJ. Metabolic pathways of the colonic metabolism of flavonoids (flavonols, flavones and flavanones) and phenolic acids. Food Chem. 2012. https://doi.org/10.1016/j.foodchem.2011.07.055.

36. Xu X, Xu P, Ma C, Tang J, Zhang X. Gut microbiota, host health, and polysaccharides. Biotechnol Adv. 2013. https://doi.org/10.1016/j.biotechadv.

37. Xu Z, Yang H, Liang GY, Gao BW, Li XQ, Leng XJ. Effects of dietary baicalein on growth, serum antioxidation indicators and flesh quality of Ctenopharyngodon idella. J Fish China. 2019b. https://doi.org/11964/jfc.20181011485.

38. Zhang AQ, Jiang HB, An M. Li M, Wang CA, Shao J, Cheng ZT. Effects of Eucommia ulmoides Oliver Bark Aqueous Extract on Growth and Muscle Quality and Texture Characteristics of Rainbow Trout (Oncorhynchus mykiss). Chinese J Anim Nutr. 2019b. https://doi.org/10.3969/j.issn.1006267x.2019.04.055. 
39. Liu C, Guo FF, Xiao JP, Wei JY, Tang LY, Yang, HJ. Research advances in chemical constituents and pharmacological activities of different parts of Eucommia ulmoides. China J Chinese Mater Med. 2019: 1-18.

40. Warner RD. The eating quality of meat-IV water-holding capacity and juiciness. In Lawrie's Meat Science (pp. 419-459). Woodhead Publishing. 2017. https://doi.org/10.1016/B978-0-08-1006948.00014-5.

41. Wang JH, He JH, Yi X, Li Y, Zhao YR. Effect of Eucommia ulmoides extract on growth performance, carcass characteristics, meat qualities and muscular amino acid contents in growing pig. Chinese $\mathrm{J}$ Anim Nutr. 2007;19:269-276.

42. Wang ZG, Pan XJ, Zhang WQ, Peng ZQ, Zhao RQ, Zhou GH. Methionine and selenium yeast supplementation of the maternal diets affects antioxidant activity of breeding eggs. Poultry Sci. 2010. https://doi.org/10.3382/ps.2009-00268.

43. Tokur B, Korkmaz K. The effects of an iron-catalyzed oxidation system on lipids and proteins of dark muscle fish. Food Chem. 2007. https://doi.org/10.1016/j.foodchem.2006.12.033.

44. Wang B, Liu Y, Feng L, Jiang WD, Kuang SY, Jiang J, et al. Effects of dietary arginine supplementation on growth performance, flesh quality, muscle antioxidant capacity and antioxidantrelated signalling molecule expression in young grass carp (Ctenopharyngodon idella). Food Chem. 2015. https://doi.org/10.1016/j.foodchem.2014.06.091.

45. Zhao HF, Feng L, Jiang WD, Liu Y, Jiang J, Wu P, et al. Flesh shear force, cooking loss, muscle antioxidant status and relative expression of signaling molecules (Nrf2, Keap1, TOR, and CK2) and their target genes in young grass carp (Ctenopharyngodon idella) muscle fed with graded levels of choline. PloS One. 2015. https://doi.org/10.1371/journal.pone.0142915.

46. Bertram HC, Oksbjerg N, Young, JF. NMR-based metabonomics reveals relationship between preslaughter exercise stress, the plasma metabolite profile at time of slaughter, and water-holding capacity in pigs. Meat Sci. 2010. https://doi.org/10.1016/j.meatsci.2009.08.031.

47. Calder PC. Polyunsaturated fatty acids and inflammation. Prostag Leukotr Ess. 2006. https://doi.org/1002/iub.1428.

48. Russo GL. Dietary n-6 and n-3 polyunsaturated fatty acids: from biochemistry to clinical implications in cardiovascular prevention. Biochem Pharmacol. 2009. https://doi.org/10.1016/j.bcp.2008.10.020.

49. Andrés S, Morán L, Aldai N, Tejido ML, Prieto N, Bodas R, Giráldez, FJ. Effects of linseed and quercetin added to the diet of fattening lambs on the fatty acid profile and lipid antioxidant status of meat samples. Meat Sci. 2014. https://doi.org/10.1016/j.meatsci.2014.02.001.

50. Starčević K, Krstulović L, Brozić D, Maurić M, Stojević Z, Mikulec Ž, et al. Production performance, meat composition and oxidative susceptibility in broiler chicken fed with different phenolic compounds. J Sci Food Agr. 2015. https://doi.org/10.1002/jsfa.6805.

51. Wu G. Amino acids: metabolism, functions, and nutrition. Amino Acids. 2009;37:1-17.

52. Berchtold MW, Brinkmeier H, Muntener M. Calcium ion in skeletal muscle: its crucial role for muscle function, plasticity, and disease. Physiol Rev. https://doi.org/10.1152/physrev.2000.80.3.1215. 
53. Wu H, Naya FJ, McKinsey TA, Mercer B, Shelton JM, Chin ER, et al. MEF2 responds to multiple calcium-regulated signals in the control of skeletal muscle fiber type. EMBO J. 2000. https://doi.org/10.1093/emboj/19.9.1963.

54. Yu E, Xie J, Wang G, Yu D, Gong W, Li Z, et al. Gene expression profiling of grass carp (Ctenopharyngodon idellus) and crisp grass carp. Int J Genomics, 2014. http://doi.org/1155 /2014/639687.

55. Oikawa H, Miyazaki S, Nishida K, Zhang W, Hirata T, Hosoo S, et al. Promotion of osteoblastic Ca ${ }^{2+}$ accumulation by Eucommia leaf extract. Glob Drugs Therap.

https://doi.org/10.15761/GDT.1000S2002.

56. Gordon MK, Hahn RA. Collagens. Cell Tissue Res. 2010; 339: 247-257.

57. Johnston IA, Alderson R, Sandham C, Mitchell D, Selkirk C, Dingwall A, et al. Patterns of muscle growth in early and late maturing populations of Atlantic salmon (Salmo salar). Aquaculture. 2000. https://doi.org/10.1016/s0044-8486(00)00372-0.

58. Guan JS, Guo HL, Zhang ZJ, Li T, Wang, ZT. Effects of Du-Zhong cortex extract on osteoblast cell proliferation, differentiation and Collal expression. Shanghai J Tradit Chin Med. https://doi.org/10.16305/j.1007-1334.2014.07.029.

59. Gorres KL, Raines RT. Prolyl 4-hydroxylase. Crit Rev Biochem Mol, 2010. https://doi.org/3109/10409231003627991.

60. Grau-Bové X, Ruiz-Trillo I, Rodriguez-Pascual F. Origin and evolution of lysyl oxidases. Sci Rep. https://doi.org/10.1038/srep10568.

61. Lauer-Fields JL, Juska D, Fields GB. Matrix metalloproteinases and collagen catabolism. Peptide Sci. 2002. https://doi.org/1002/bip.10201.

62. Nishimoto M, Mizuta S, Yoshinaka R. Characterization of molecular species of collagen in muscles of Japanese amberjack, Seriola quinqueradiata. Food chem. 2004. https://doi.org/10.1016/S03088146(03)00183-3.

63. Michelin AC, Justulin LA, Delella FK, Padovani CR, Felisbino SL, Dal-Pai-Silva M. Differential MMP-2 and MMP-9 activity and collagen distribution in skeletal muscle from pacu (Piaractus mesopotamicus) during juvenile and adult growth phases. Anat Rec. https://doi.org/10.1002/ar.20863.

64. Chen HB, Chen JC, Li G, Chen, HL. Effects of Eucommia Ulmoides Extract on MMP-2 and TIMP-2 Expression in Rat Vascular Endothelial Cells. Mod Pract Medicine. https://doi.org/311313.10.3969/j.issn. 1671-0800.2018.03.012.

65. Wang JY, Chen XJ, Zhang L, Pan YY, Gu ZX, He SM, et al. Comparative studies of different extracts from Eucommia ulmoides against rheumatoid arthritis in CIA rats. Evid-Based Compl Alt, 2018b. https://doi.org/10.1155/2018/7379893.

\section{Figures}



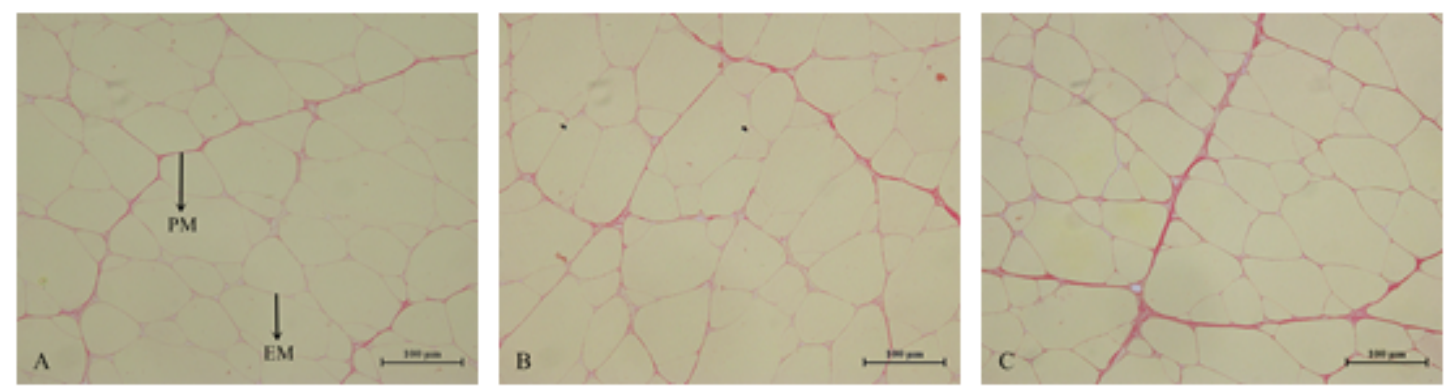

\section{Figure 1}

Muscle tissue transverse sections of grass carp. A: Control; B: EBE; C:ELE; PM: Perimysium; EM: Endomysium



Figure 2

Relative collagen-related genes expression levels in flesh of grass carp fed Eucommia extracts diets Values in the same row with different superscripts alphabets indicate significant differences $(p<0.05)$ 